\title{
子どもにおける運動・スポーツ活動と運動遊びの意義とは ーヘルスアウトカムとの関連から探るー
}

\author{
引原 有輝 $^{1}$, 渡邊 將司 $^{2}$, 川勝 佐希 ${ }^{3,4}$, 石井 好二郎 ${ }^{5}$
}

\section{Benefits of organized sports participation and voluntary outdoor play in children and adolescents based on evidence-related health outcomes}

\author{
Yuki Hikihara $^{1}$, Masashi Watanabe ${ }^{2}$, Saki Kawakatsu ${ }^{3,4}$ and Kojiro Ishii ${ }^{5}$ \\ ${ }^{1}$ 千葉工業大学創造工学部, †275-0023 千葉県習志野市芝園2-1-1 (Faculty of Creative Engineering, Chiba Institute of \\ Technology, 2-1-1 Shibazono, Narashino, Chiba 275-0023, Japan) \\ 茨城大学教育学部, ₹310-0056 茨城県水戸市文京2-1-1 (College of Education, Ibaraki University, 2-1-1 Bunkyo, Mito, \\ Ibaraki 310-0056, Japan) \\ 3 神戸大学大学院人間発達環境学研究科， ₹ 657-0011 兵庫県神戸市灘区鶴甲3-11 (Graduate School of Human and Envi- \\ ronment, Kobe University, 3-11 Tsurukabuto, Nada-ku, Kobe, Hyogo 657-0011, Japan) \\ ${ }^{4}$ 日本学術振興会，７102-8472 東京都千代田区趐町 5-3-1 (Japan Society for the Promotion of Science, 5-3-1 Kouzimachi, \\ Chiyoda-ku, Tokyo 102-8472, Japan) \\ 5 同志社大学スポーツ健康科学部， =610-0394 京都府京田辺市多々羅都谷1-3 (Faculty of Health and Sports Science, Dosh- \\ isha University, 1-3 Tatara-Miyakodani, Kyotanabe, Kyoto 610-0394, Japan)
}

Received: July 19, 2017 / Accepted: November 14, 2017

\begin{abstract}
This report provides an overview of the effectiveness of objectively measured physical activity, sports participation, and outdoor play on outcomes related to mental health and social skills in children and adolescents. Findings based on observation studies of longitudinal and cross-sectional design are inconsistent. On the other hand, several intervention studies with high intensity exercise programs indicated that intensity and amount of physical activity might provide a short-term benefit against depressive symptoms and anxiety. However, there are reports that psychosocial approaches confer effects similar to exercise programs. The effects of participation in organized sports clubs on mental health conditions such as depression, anxiety, self-esteem, self-efficacy, health-related quality of life, social skills (e.g., relationship skills), and coping ability were diverse. Notably, there could be unfavorable relationships in athletes exhibiting a higher performance. Meanwhile, participation in sports could represent a predictor of escalation in alcohol use as evidenced by longitudinal observation studies in adolescent, although there could also be effectiveness in terms of preventing use of illicit drugs. Lastly, active outdoor play under natural conditions without supervision also represented an effective approach to promote mental health (e.g., reducing depressive symptoms and building social skills such as self-regulation and coping skills in the face of difficult human relationships). We recognize that not only sports participation but also outdoor play under abundant nature environment could represent a significant physical activity to maintain mental and social health from childhood to adolescence.
\end{abstract}

Jpn J Phys Fitness Sports Med, 67(1): 83-98 (2018)

Keywords : sports participation, outdoor play, psychological health, social skill, children

\section{緒言}

社会構造や生活様式の変化と共に子どもの健康問題は 多様化し，またそれらは複雑に関連し合っていることが 指摘されている1)。そのような現状の中，発育期の子ど もが身体活動を実践することによって得られる健康上の 恩恵には多数かつ多面的な報告がある。例えば，身体活
動が肥満予防，体力向上，生活習慣病やそのリスク因子 の予防・阻止など身体的な健康に寄与することが明らか となっている ${ }^{2)}$. また, 身体活動は抑うつ傾向の改善, 健康関連 QOL の高揚 ${ }^{3}$, ささらに, 将来にわたるアクティ ブライフの獲得，非行やドラッグなどの非社会的行動の 抑止に寄与することなどが報告されている4).

これらの身体活動とへルスアウトカムとの関連を報告 
した数多くの研究では, 元々, 身体活動が広義であるこ とに加え, 身体活動の評価法の発展に伴って用いられる 指標が多様化したこともあり，その恩恵や効果について 統一的な見解が得られておらず，またそれらの知見を整 理することも簡単ではない，例えばBangsbo ら ${ }^{5)}$ は，子 どもの運動・スポーツを含む中高強度の身体活動（moderate to vigorous physical activity: MVPA）がもたらす 身体的健康, 認知機能, 精神的健康, 社会スキルへの恩 恵について, 学校活動と余㗇活動の視点から捉えたコン センサスを示している。このような国際的な身体活動指 針や声明では肥満予防や体力向上に寄与する身体活動の 強度の側面が意識されていることもあり, 子ども期（主 に小学生から高校生）にはその必要条件を達成しやすい 運動・スポーツ活動が積極的に推奨されている.したがっ て, 運動・スポーツ活動とMVPAをほぼ同義に扱って しまうことも多い.しかしながら両者の概念は異なって 掞り，運動・スポーツ活動とMVPAがもたらす子ども への恩恵やそれらの意義も異なっているはずである。ま た子どもには, 身体活動の主たる構成要素である遊び(主 に体を使った運動遊び）がある，遊びの定義は不確定な がら，組織的な運動・スポーツ活動（主にスポーツクラ ブや学校体育）とは異なり, 明確なルールや第三者（親, 教師，コーチ）に統制が図られることは少ないため，子 ども自身が主体的に選択できる自由な身体活動である点 で他の概念と一線を画す。しかし研究調查レベルで遊び を正確に評価することは必ずしも容易でないことから， 強度の側面による評価指標が中心となる場合が多い。こ の評価の仕方では運動・スポーツ活動と遊びを区別する 必要がないため, 結果的に遊びという身体活動の形態や 条件がもたらす恩恵を明らかにするには至らず，その恩 恵は強度や量によるという結論が導かれてしまう。指針 の策定根拠にもなっているように身体活動がもたらす恩
恵は主として肥満予防，生活習慣病のリスク軽減，体力 向上など直接的な効果が現れやすい身体的側面に由来す る場合が多く，その場合にはどうしても強度と量の側面 に主眼が置かれやすい。

一方，冒頭に示したように抑うつ傾向などの精神的な 健康状態とも相互関連があるライフスキルを含む社会久 キルなどのヘルスアウトカムにおいては, 必ずしも強度 の側面に限るものでなく, 運動・スポーツや遊びの活動 形態がもたらすメリットがあると考えられる，残念なが ら，それらのアウトカムに対する身体活動の効果は曖昧 あるいは混同してしまう点が多く，それは主に身体活動 の評価法にも問題のあった可能性がある。例えば，質問 紙票の場合では集団の代表值として身体活動量を評価す ることは可能であるが，個人間差を客観的に評価するこ とには限界があり ${ }^{6)}$ ，身体活動の評価法が質問紙票から 加速度計に代わることで結論が異なってしまうことがあ る ${ }^{7,8)}$ ，そのため信頼性のある身体活動の指標や活動形態 ならびに研究デザインに即して, 今一度その恩恵につい て整理しておくことが必要と考えられる.

そこで本研究では, メンタルヘルス, 社会スキル，健 康行動を主たるへルスアウトカムとし，子ども期（主に 小学生から高校生）の運動・スポーツ活動がもたらす恩 恵について，Fig. 1に示すような身体活動の評価の観点 (身体活動強度や非組織的な遊び) から得られた成果も 踏まえながら概観することを目的とした。

\section{身体活動強度とメンタルヘルス}

身体活動を歩数計や加速度計などの客観的手法により 評価した観察研究に限定すると, Strauss ら ${ }^{9)}$ が10〜16 歳を対象にMVPA（主に3.0 METs以上）と自己肯定感 （self-esteem）ならびに慢性的不安との関連を報告して おり, 高強度 (vigorous physical activity: VPA, 主に6.0

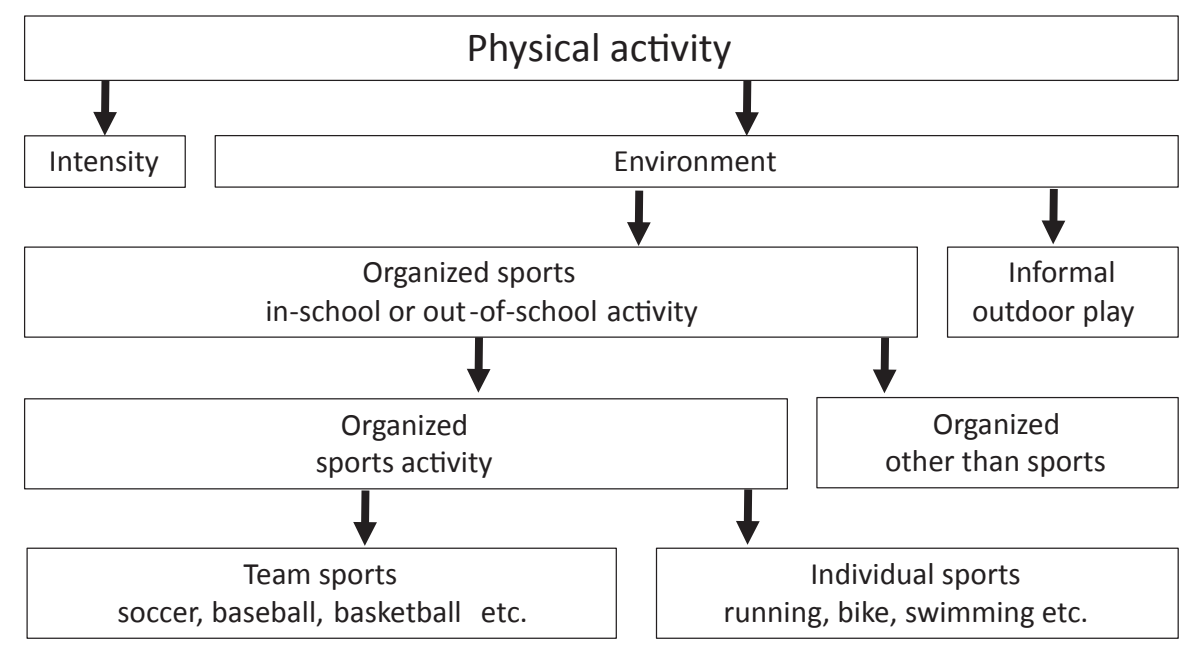

Fig. 1 Viewpoints on classification of physical activity 
METs 以上）と自己肯定感との間に有意な関連性がある ことを示している。また，9〜10歳を対象にしたParfitt ら ${ }^{10)}$ の研究では, VPA（6.0 METs以上）とメンタルヘ ルス（不安, 抑うつ）との間に負の関連が, 自尊心との間 に正の関連があったことを示している（Table 1)。しか しながら，最近報告されたPoitras ら ${ }^{3)}$ のレビュー論文 では，身体活動と健康関連 QOL，Well-being，精神的 苦恼 (psychological distress, depression symptoms), 自 己肯定感との関連を扱った計 8 編の観察研究の結果につ いて, 上述の 2 つの論文とは異なる興味深い結論を示し ている. 8 編のうち横断研究が 6 編, 縦断研究が 2 編で あった，横断研究では， 6 編中 2 編 $^{11,12)}$ においてMVPA や総歩数と一部のメンタルヘルス指標との間に好ましい 関係 (favorable) を認めているが, 残り 4 編 ${ }^{13-16)}$ は主に MVPA との間には無関係（null）もしくは否定的な関係 (unfavorable) を報告している。また縦断研究 2 編 ${ }^{17,18)}$ では, いずれも MVPA (3 or 4 METs以上) やエネルギー 消費量との間に無関係もしくは効果が認められないとい う結論に至っている（Table 1)。すなわち，身体活動強 度とメンタルヘルスとの関係を明らかにするにあたり， 横断研究が大半であるため, Guyattら ${ }^{19)}$ のエビデンス 評価に基づいて全般的に研究の質が低いとされているこ とや，結論を導くうえで論文数の限られていることが指 摘されている. Poitras ら ${ }^{3)}$ のレビュー論文以降の観察研 究 ${ }^{20-23)}$ を探ると, 効果を認める追跡研究もあるが確定的 な結論は得られない (Table 1).

そこで，身体活動の強度的側面が子どものメンタルヘ ルスの維持, 改善に有効であるかについて介入研究の結 果を参照したい. Biddle and Asare ${ }^{24)} に よ り$ 報告された 論文は，メ夕解析されたレビュー論文をまとめたもので あり, 主に無作為抽出比較対照試験 (randomized-control trial: RCT) やnon-RCTを用いた介入研究に関する知見 が大半である（Table 2). 介入効果の対象となった身体 活動は主に柔軟体操やダンス, 筋力トレーニングならび にランニングなど複数の運動形態を含んだ運動プログラ ムであるが, いずれのプログラムも少なくとも中高強度 以上の運動が含まれており身体活動における強度の効果 を明らかにする上で参考となる。この論文では抑うつ傾 向, 不安感, 自尊感情（self-esteem, self-concept）をアウ トカムとしている。例えば, 抑うつ傾向では, Calfas and Taylor $^{25)}$ による 4 つ介入研究の効果量 (effect size: ES) が-0.38であり, 中高強度の運動プログラムに一定の効 果を見出しているものの, Craft and Landers ${ }^{26)}$ は運動プ ログラムの効果は小さく期待できるものではない（ES: -0.15, no significant）と報告しており, やや見解が異なる. 不安感においても, Calfas and Taylor ${ }^{25)}$ と Wipfli ${ }^{27)}$ は運 動プログラムの ESがそれぞれ-0.15および-0.19であり 統計的な有意性は認められなかったことを報告してい
る。さらに, Larun ら ${ }^{28)}$ は, 高強度活動を含んだ運動プ ログラムの ESは-0.48であったとしているが，低強度活 動や心理社会的な手法を用いたアプローチとの間に効果 の差異は認められなかったことを報告している．自尊感 情では，運動プログラムによる効果は運動技能の獲得や 体型への認識などの身体に対する自己肯定感というある 一部の側面での効果に過ぎないという報告 ${ }^{25)}$ や，運動に よる介入の効果（ES: 0.49）を短期的（8 週間から 20 週 間）にみた報告であることが指摘されている ${ }^{29)}$ 。また, Biddle and Asare ${ }^{24)}$ の総説論文において注意すべき点 は，対象者特性である。年齢では幼少期から大学生が含 まれており，またバックグラウンドでは中軽度の抑うつ 症状を有する者や，違法犯罪者，素行不良者などが含ま れていることから，運動介入の効果（量一反応関係）の 解釈には注意する必要があり，対象者に応じた効果の整 理が今後の課題であると考えられる.

さて国内では，川勝らのグループ30,31) が，身体活動強 度とメンタルヘルスとの関連について検討しており，小 学生, 中学生ともにVPAが 3 時間半以上/週, さらに小 学生ではMVPAが 3 時間半以上/週の実施時間が抑うつ の予防の目安となる可能性について報告している ${ }^{31)}$ 。し かしながら, 国内での大規模な調査研究は, 川勝らがス タートさせたばかりであり，活動量計の導入や追跡調査 などこれからの発展が期待される.

まとめると, 以上の総説論文により示唆されることは, 身体活動の強度的側面が精神的健康面に寄与するという 明確な結論を導くことは難しく，身体活動の実践そのも のが重要であるという可能性もある。また，他の心理社 会的アプローチによっても運動プログラムと近似した成 果が獲得される可能性があるため, メンタルヘルスに寄 与する運動やスポーツにおいて, 強度的側面以外の要因 にも着目する必要があると考えられる。

\section{組織的・体系的な運動・スポーツへの参加と ヘルスアウトカム}

メンタルヘルスならびに社会スキルとの関連 国内の報 告では, 永松 ${ }^{32)}$ の総説論文を参照すると, 運動部活動の 効果について，高校生を対象に社会スキル（ライフスキ ル）に関する報告が 1 編, 高校生を対象にメンタルヘル スに関する報告が 6 編，中学生を対象に社会スキル（人 間関係の構築）に関する報告が 1 編であった。いずれも 運動部活動への参加や継続がメンタルヘルス, 社会ス キルに良好な影響をもたらす可能性を示唆しているが, 700 名以上を対象に追跡調査（15ヶ月間）を行った研究 は永松 ${ }^{32)}$ のみであり，大半が横断研究であった。またサ ンプル数は一部2000名超える研究も見られるが, 大半が 100〜 500名程度の比較的小規模であった。

一方，国外の研究の動向に目を向けると, Eime ら ${ }^{33)}$ 


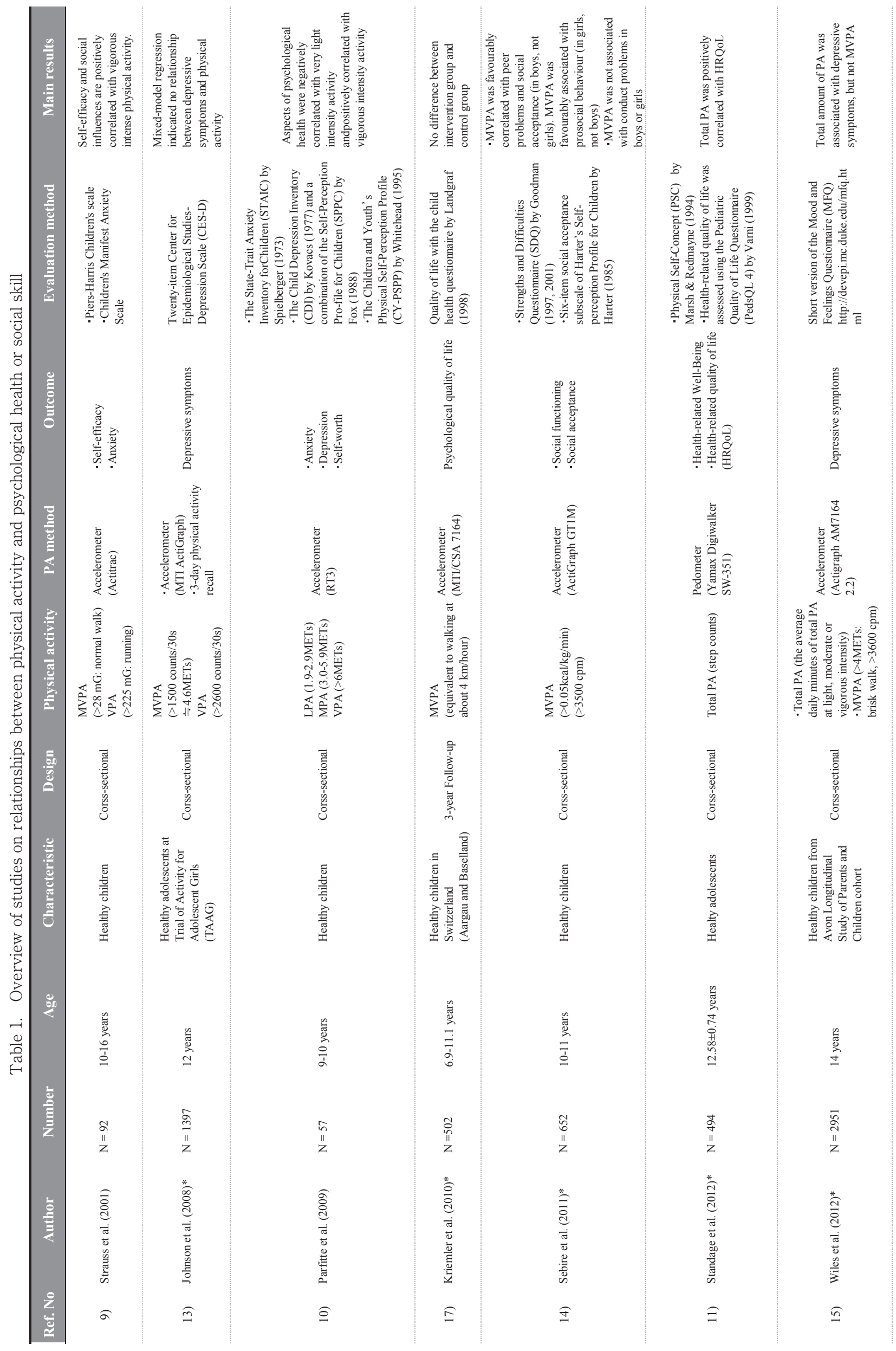




\begin{tabular}{|c|c|c|c|c|c|c|c|}
\hline 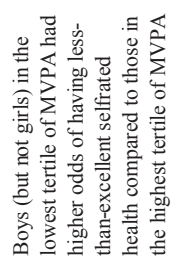 & 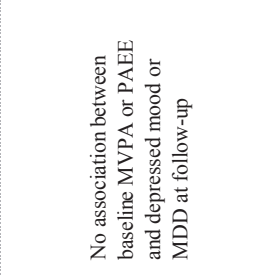 & 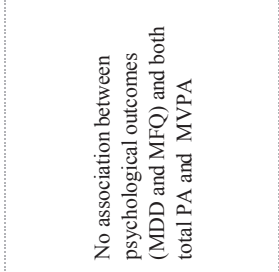 & 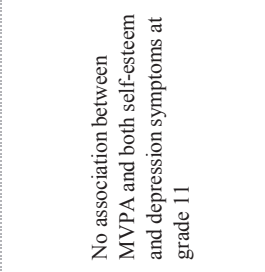 & 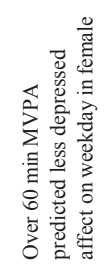 & 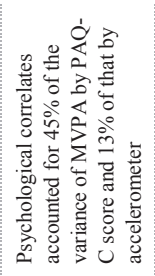 & 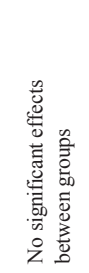 & 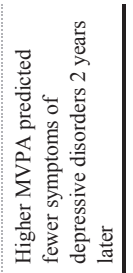 \\
\hline 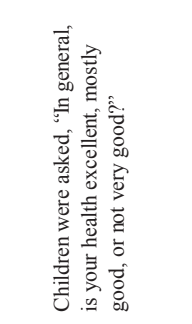 & 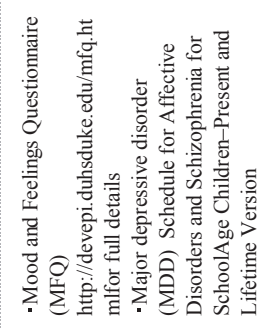 & 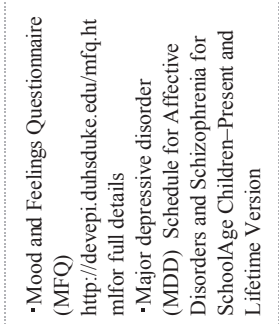 & 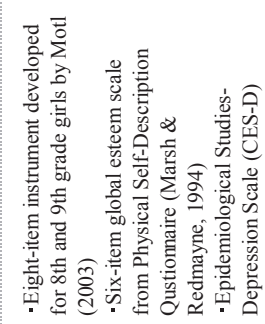 & 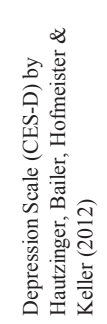 & 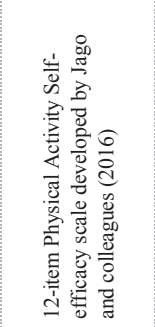 & 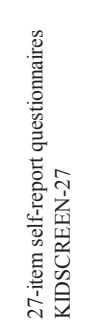 & 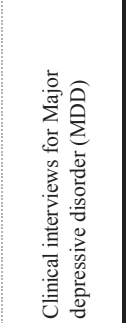 \\
\hline 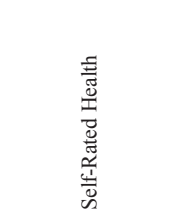 & 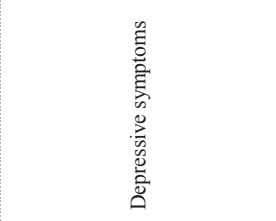 & 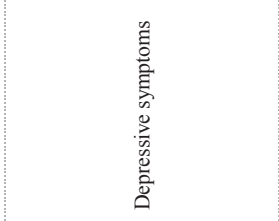 & 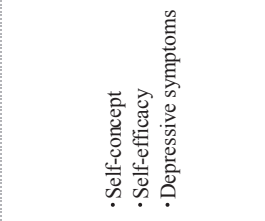 & 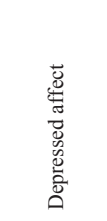 & 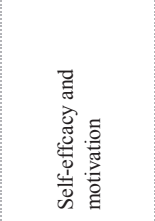 & $\begin{array}{l}\text { 量 } \\
\frac{0}{0} \\
\frac{10}{\overline{0}} \\
3 \\
3\end{array}$ & 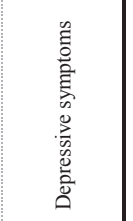 \\
\hline 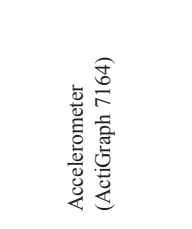 & 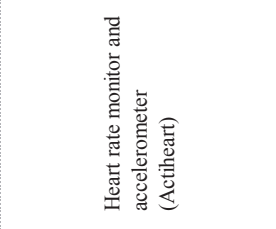 & 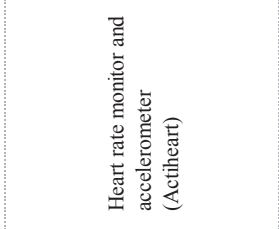 & 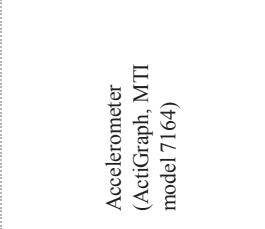 & 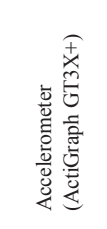 & 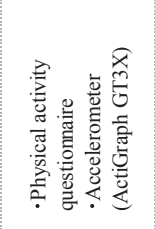 & 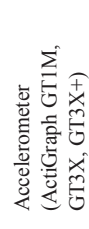 & 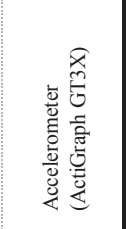 \\
\hline 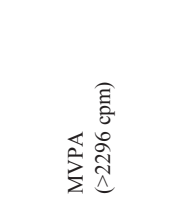 & 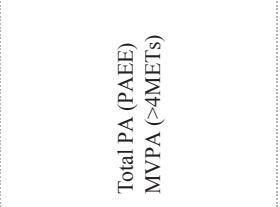 & 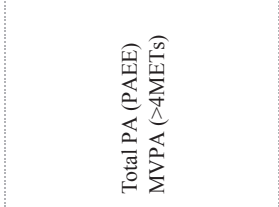 & 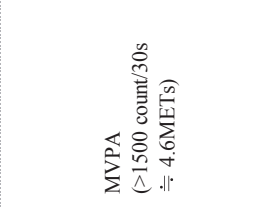 & 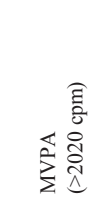 & 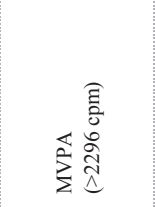 & 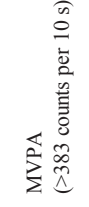 & 焉 \\
\hline 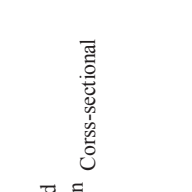 & 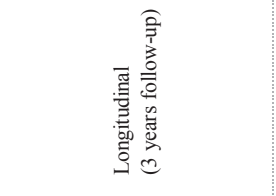 & 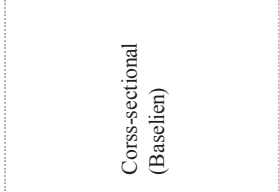 & 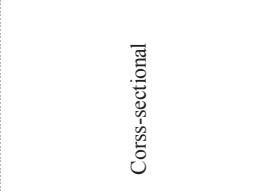 & 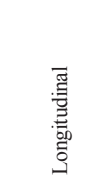 & 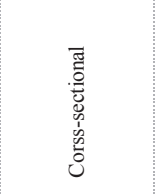 & 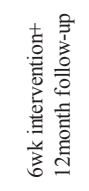 & 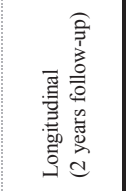 \\
\hline 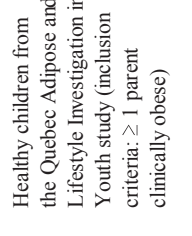 & 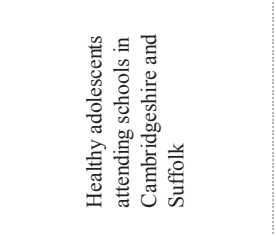 & 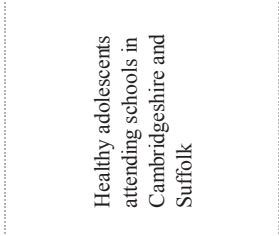 & 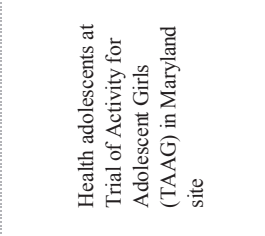 & 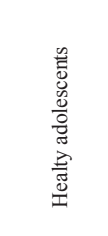 & 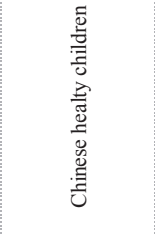 & 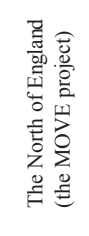 & 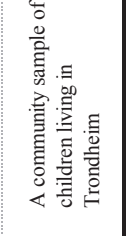 \\
\hline 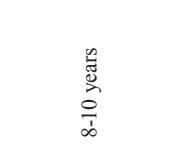 & 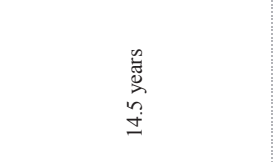 & 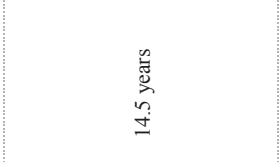 & 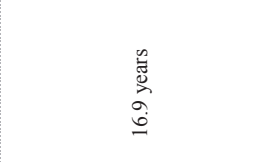 & 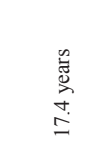 & 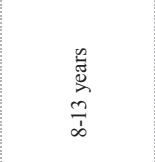 & 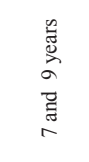 & 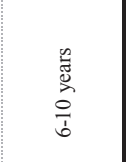 \\
\hline $\begin{array}{l}\text { స̃ } \\
\text { z }\end{array}$ & 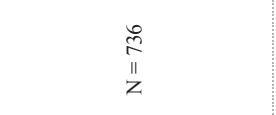 & $\underset{\substack{i \\
z}}{\stackrel{\infty}{z}}$ & $\begin{array}{l}\infty \\
\text { in } \\
\text { in } \\
z\end{array}$ & $\begin{array}{l}\pi \\
\pi\end{array}$ & $\begin{array}{l}\text { g } \\
\text { z }\end{array}$ & 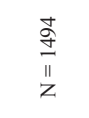 & 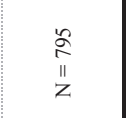 \\
\hline 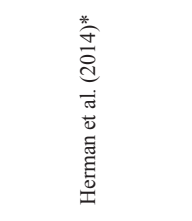 & 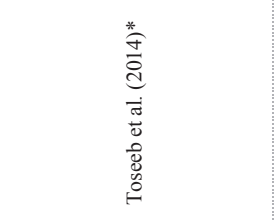 & 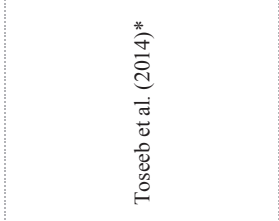 & 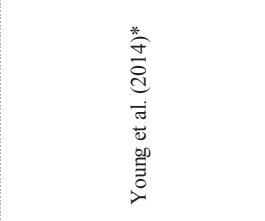 & 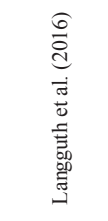 & 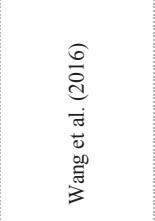 & 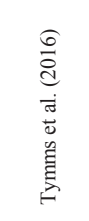 & 离 \\
\hline$\widehat{త}$ & $\stackrel{\infty}{\underline{D}}$ & 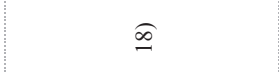 & $\subseteq$ & $\widehat{\AA}$ & $\widehat{\pi}$ & $\widehat{\vec{v}}$ & $\widehat{\nwarrow}$ \\
\hline
\end{tabular}


Table 2. Effects of physical activity on children's psychological health shown in a review paper ${ }^{24)}$

\begin{tabular}{|c|c|c|c|c|c|c|}
\hline Authors & Stduies & Outcome & Sample & Intervention & Effect & \\
\hline \multirow{3}{*}{ Calfas \& Taylor $(1994)^{25)}$} & 4 & Depression & \multirow{3}{*}{$\begin{array}{l}\cdot \text { Healthy students } \\
\cdot \text { Healthy colledge students } \\
\cdot \text { Psychiatric inpatients } \\
\cdot \text { Youth offenders } \\
\cdot \text { Juvenile delinquent } \\
\cdot \text { Learning disabilities } \\
\cdot \text { - Autistic }\end{array}$} & \multirow{3}{*}{$\begin{array}{l}\text { Stretch exercise, vigorous } \\
\text { physical activity such as } \\
\text { running }\end{array}$} & -0.38 & B \\
\hline & 3 & Anxiety & & & -0.15 & $\mathrm{C}$ \\
\hline & 3 & Self-esteem & & & 0.12 & $\mathrm{C}$ \\
\hline Craft \& Landers $(1998)^{26)}$ & 3 & Depression & Inpatients & $\begin{array}{l}\text { Vigorous physical activity } \\
\text { such as aerobic and } \\
\text { anaerobic exercise }\end{array}$ & -0.15 & $\mathrm{C}$ \\
\hline Ekeland et al. $(2004)^{29)}$ & 8 & Self-esteem & $\begin{array}{l}\cdot \text { Healthy young children } \\
\cdot \text { Health elementary school children } \\
\cdot \text { - Learning disabilities } \\
\cdot \text {-Juvenile delinquents } \\
\cdot \text {-Youth offenders }\end{array}$ & $\begin{array}{l}\text { Daily physical activity } \\
\text { including vigorous physical } \\
\text { activity }\end{array}$ & 0.49 & B \\
\hline \multirow{2}{*}{ Larun et al. (2006) ${ }^{28)}$} & 5 & Depression & \multirow{2}{*}{$\begin{array}{l}\text { - Depressive symptoms adolescents } \\
\text { - Elementary school children } \\
\text {-Special education students } \\
\text { - Youth offenders } \\
\text { - Healthy university students }\end{array}$} & \multirow{2}{*}{$\begin{array}{l}\text { Modetate to vigorous } \\
\text { physical activity such as } \\
\text { walking and running for } \\
\text { improving cardiovascular } \\
\text { fitness }\end{array}$} & -0.66 & A \\
\hline & 6 & Anxiety & & & -0.48 & B \\
\hline Wipfli et al. (2008) ${ }^{27)}$ & 3 & Anxiety & $\begin{array}{l}\text {-Health elementary school children } \\
\text { (middle-class family) } \\
\cdot \text { 'Youth offenders } \\
\cdot \text { Colledge students }\end{array}$ & $\begin{array}{l}\cdot V \text { Vigorous physical activity } \\
\text { such as aerobic and } \\
\text { anaerobic exercise, running } \\
\cdot \text { Physical fitness programs }\end{array}$ & -0.19 & $\mathrm{C}$ \\
\hline
\end{tabular}

${ }^{*}$ A shows the absolute value of more than 0.60. B shows the absolute value from 0.20 to 0.59 . C shows the absolute value below 0.20 .

のレビュー論文では，計 30 編の論文が対象となってお り，運動・スポーツ参加とメンタルヘルス (outcome数 では50）との関連の報告が78.1\%, 社会スキル（outcome 数では14）との関連の報告が $21.9 \%$ であった（Table 3). この論文で提案されているスポーツ概念モデルでは, 運 動・スポーツを通じた社会スキルの獲得とメンタルヘル スとの相互関連があることを前提に，「組織的と非組織 的」拈よび「チームスポーツと個人スポーツ」の主に 2 つの視点から, 運動・スポーツを通じて得られる精神的, 社会的恩恵についてまとめている. 対象となった研究デ ザインの特徵として，21編の横断研究 (outcome数では 45）が $70.3 \% ， 9$ 編の縦断研究 (outcome数では19) が $29.7 \%$ であり, エビデンスレベルとしては低い横断研究 が多数を占めている。この総説論文の対象となった研究 では，いずれも運動・スポーツ活動への参加とメンタル ヘルスや社会スキルとの間に好ましい（favorable）関係 が示されている.また, 個人スポーツよりもチームスポー ツの方に抏いて，それによって得られる恩恵が大きいこ とや，組織的な運動・スポーツと他の組織的活動（文化 芸術活動, 宗教活動, ボランティア活動）の両方に参加し ていることは，何より効果が大きい可能性があるが，他 の組織的活動以上に運動・スポーツ活動による恩恵の大 きさについて併せて述べられている，さらに，運動・ス ポーツの種目や経験年数, 実施頻度なども精神的, 社会 的な恩恵の程度を決定する要因となる可能性について指 摘している.ただし,この総説論文には含まれていないが,
運動・スポーツ活動に所属している者を対象に抑うつ症 状 ${ }^{34)}$ や自殺願望や自殺行為 ${ }^{35}$.36) をアウトカムにして身体 活動の量 (頻度) や強度との関連を試みたところ, 有意 性は認められなかったことも明らかにされている。この レビュー論文が報告された2013年以降についても複数の 研究が, 組織的な運動・スポーツへの参加によって良好 なメンタルヘルスや社会スキルの獲得に寄与するという 結論を支持している（Table 4)。Guèvremontら ${ }^{37)}$ は14 ～17歳を対象に, 学校外のスポーツ課外活動と不安感, 自己肯定感，そして学力との間に好ましい関係があるこ とを報告している。ささらに，学外に加え，学内のスポー ツ活動にも所属している場合にはその関係性が強まるこ とも併せて述べている。 また，McMahonら ${ }^{38)} は ，$ 単に 国際的な身体活動の推奨基準值を満たしている頻度（日 数）が多いことよりも，むしろ運動・スポーツ活動に参 加していることの方がメンタルヘルスへの付加的な効果 となることを報告している.

縦断研究の視点からは, Vella $5^{39,40)}$ が 2 年間追跡調 查の結果に基づいて, 運動・スポーツ活動に継続的に参 加している子どもは，途中でドロップアウトした子ども と比較して, 精神的困難の程度を表す数值が低いことや, 追跡期間中に運動・スポーツ活動に参加していない子ど もよりも内面的問題（感情表現や人間関係）を表す数值 が低いことを明らかにしている，さらに，8年間の追跡 研究から健康関連 QOLへの効果があることも報告して いる ${ }^{41)}$ 。また，児童期高学年から中学校期，高校期にお 
ける運動・スポーツ活動への参加は，若年成人期におけ る抑うつ傾向の抑制に効果のある可能性が長期の追跡研 究により明らかにされている34,42-44).

一方で横断研究ではあるが, Baduraら ${ }^{45)}$ は11〜15歳 を対象に, 運動・スポーツに限らず文化芸術活動（音楽, ダンス, 合唱, 演劇) を含む組織的な余㗇活動と, 生活へ の満足感や気分（落ち込み, 不機嫌, 神経質, 不眠) など のメンタルヘルスとの関係には, 性差や年齢差の要因が あることを報告している。すなわち, 男子や年齢の高い 子どもの場合はチームスポーツも個人スポーツもメンタ ルヘルスと好ましい関連を示したが, 女子や年齢の低い 子どもの場合では，文化芸術活動（ただし，多くの者が スポーツ活動への所属もあり）へ参加している方がメン タルヘルスとより強く好ましい関連にあったことを示し ている.

このように, 組織的なスポーツ活動に参加することに よる子どもの社会的, 心理的メリットが大きいことが証 明されているが, これらの知見の大半は横断研究に基づ くものであり, 両者の因果関係を証明するためのエビデ ンスレベルとしては依然弱いため, 今後は因果関係の究 明に加えて, 性別や年齢, さらには人種も考慮した新た な報告が待たれる。また，Pichéら ${ }^{46)}$ の報告によれば， 積極的に幼稚園の学級行事に従事した者ほど, 小学 4 年 生時の運動・スポーツの実施率が高いことを認めている. すなわち, 児童期の運動・スポーツ参加には, 就学前の 人間関係の経験の豊かさが重要となることを示唆してお り，運動・スポーツ参加と社会スキルには相互に作用し ている可能性が予想される。ただし, 運動・スポーツと メンタルヘルスとの関連性には慎重な見方をしている報 告もある．特に，スポーツ競技会に積極的に参加するア スリートでは上述してきた知見とは異なる可能性がある ため ${ }^{47,48)}$, 組織的運動・スポーツへの参加とメンタルヘ ルスとの関係には, 競技レベルも考慮すべき要因として 考えられている.
以上のことを踏まえると，運動・スポーツ活動による 恩恵とは，集団活動の中での育まれる社会スキル，ライ フスキル，コーピングスキルに分類される自己開示， ス トレス対処, リーダーシップ, 集団行動, コミュニケー ション，目標遂行などのスキルの獲得がなされることで あろうと考えられる。詳細なメカニズムは明らかにされ てはいないものの, 運動・スポーツ活動に限らず, 他の 芸術的あるいは文化的活動でも類似した恩恵を享受する ことが可能である。ただし, 組織的活動とメンタルヘル スとの関係において，身体活動（強度や頻度）という変 数が介在することで, 得られる恩恵はさらに大きくなる 可能性がある。しかしながら，エリート競技選手におい ては勝利至上主義がもたらす過度なストレスや劣等感, 燃え尽き症候群なども報告されており，行き過ぎた運動・ スポーツ活動がデメリットになるケースも多分にあるこ とを忘れてはならない ${ }^{48)}$.

飲酒, ドラッグなどの非健康行動との関連 組織的な運 動・スポーツへの継続的な参加活動は, 精神的ストレス を軽減し，さらにはストレス対処スキルを高めることが わかっている。そして，自尊感情が高まり，自己統制力 や忍耐力, 規律心への寄与に関する報告もみられた。 そ こで, 運動・スポーツへの参加と非健康行動との関連に も着目したい. Pateら ${ }^{4)}$ は, アメリカ人高校生 14211 人 を対象に, 運動・スポーツ参加者は, 非参加者と比較して, ドラッグ, 性行動, 自殺行為（願望）などの非健康行動 におけるオッズ比が有意に低いことを報告している。た だし，飲酒におけるオッズ比には差が認められていない. またカナダの中高生を対象にした研究では, 学校外の組 織的な活動に参加している者は，契煙，飲酒，薬物使用 におけるオッズ比が有意に低いが，学内外の組織的な運 動・スポーツへの参加は, それらの非健康行動の発生確 率を高める可能性が報告されている ${ }^{37,49,50)}$ 。一方，国内 に目を向けると，高校生を対象にしてクラブ活動および

Table 3. The numbers of studies on relationships between sports participation and psychological health or social skill by types of study design in a review paper ${ }^{33}$ )

\begin{tabular}{lccc}
\hline \multicolumn{1}{c}{ Design/Outcome } & Psychological parameters $^{\mathrm{a})}$ & Social skills $^{\mathrm{b})}$ & Total number (\%) \\
\hline Cross-sectional $^{\mathrm{c})}$ & 35 & 10 & $45(70.3 \%)$ \\
Longitudinal $^{\mathrm{c}}$ & 15 & 4 & $19(29.7 \%)$ \\
\hline Total number (\%) & $50(78.1 \%)$ & $14(21.9 \%)$ & $64(100 \%)$ \\
\hline
\end{tabular}

a) Psychological parameters: assertive, caring, competence, confidence, emotional control, regulation, self-efficacy, well-being, depressive symptoms, health perceptions, distress, hopelessness, suicidality, satisfaction, positive affect, anxiety, self-control, self-esteem, youth development

b) Social skills: cooperation, human relationship, social interaction, sportsmanship, teamwork, self-concept

c) Each value shows a sum of health outcomes 
Table 4. Overview of studies on relationships between sports participation and psychological health or social skill since 2013

\begin{tabular}{|c|c|c|c|c|c|c|c|c|}
\hline Ref. 1 & Author & Number & Age & Design & Physical activity & Outcome & Evaluation method & Main results \\
\hline 42) & Sabiston et al. (2013) & $\mathrm{N}=860$ & $12-13$ years & $\begin{array}{l}\text { Longitudinal } \\
\text { (8 years follow-up) }\end{array}$ & Sports paticipation & Depressive symptoms & $\begin{array}{l}\text { Questionnaire, Depressive } \\
\text { symptom scale by Kandel \& } \\
\text { Davies (1982) }\end{array}$ & $\begin{array}{l}\text { High depressive symptoms } \\
\text { trajectories during adolescence } \\
\text { were negatively associated with } \\
\text { the number of organized sports } \\
\text { team in early adulthood }\end{array}$ \\
\hline 34) & Brunet et al. (2013) & $\mathrm{N}=1293$ & $12-13$ years & $\begin{array}{l}\text { Longitudinal } \\
\text { (10 years follow-up) }\end{array}$ & Sports participation & Depression & $\begin{array}{l}\text { - Major Depression Inventory } \\
\text { (MDI) }\end{array}$ & $\begin{array}{l}\text { Sports participation but not } \\
\text { MVPA at baseline may } \\
\text { positively depresiion in early } \\
\text { adulthood. However, the } \\
\text { association by adjusted } \\
\text { regression model is very weak } \\
\left(\mathrm{R}^{2}=0.11\right)\end{array}$ \\
\hline 40) & Vella et al. (2014) & $\mathrm{N}=4042$ & $8-10(8.25)$ years & $\begin{array}{l}\text { Longitudinal } \\
\text { (2 years follow-up) }\end{array}$ & $\begin{array}{l}\text { Sports participation } \\
\text { (Team sports vs. } \\
\text { individual sports) }\end{array}$ & $\begin{array}{l}\text { Health-related QOL } \\
\text { (HRQOL) }\end{array}$ & $\begin{array}{l}\text { Parent report version of Pediatric } \\
\text { Quality of Life Scale (PedsQL) } \\
4.0 .\end{array}$ & $\begin{array}{l}\text {-Children who continued to } \\
\text { participate in sports had greater } \\
\text { HRQOL comapred with others } \\
\text { (not participation, commenced, } \\
\text { dropout) } \\
\cdot \text { Children 's participation in } \\
\text { team sports more helps to } \\
\text { protect HRQOL than individual } \\
\text { sports }\end{array}$ \\
\hline 37) & Guèvremont et al. (2014) & $\mathrm{N}=3202$ & $\begin{array}{l}14-17 \text { years } \\
(\text { mean } 15.40 \pm 0.66)\end{array}$ & Cross-sectional & $\begin{array}{l}\text { In-school or out-of-school } \\
\text { extracurricular activities } \\
\text { including sports } \\
\text { participation }\end{array}$ & $\begin{array}{l}\text { Socioemotional outcomes } \\
\text {-pro-social behavior } \\
\text {-self-image } \\
\cdot \text { depresiion } \\
\text { - hyperactivity } \\
\text {-physical aggression }\end{array}$ & $\begin{array}{l}\text {-Canadian modified version of } \\
\text { Child Behaviors Checklist } \\
\cdot \text {-Ontario Child Halth study }\end{array}$ & $\begin{array}{l}\text { Youth who participated in out- } \\
\text { of-school activities or in both in- } \\
\text { school and out-of-school } \\
\text { activities had better } \\
\text { socioemotional outcomes }\end{array}$ \\
\hline 43) & Jewett et al. (2014) & $\mathrm{N}=853$ & $\begin{array}{l}20.39 \text { years } \\
\text { (adolescens to early } \\
\text { adulthood) }\end{array}$ & Longitudinal & Sports participation & $\begin{array}{l}\cdot \text { Depressive symptoms } \\
\cdot \text { Perceived stress } \\
\cdot \text { Self-rated mental health }\end{array}$ & $\begin{array}{l}\text {-Major Depression Inventory } \\
\text { (MDI) } \\
\text {-Canadian Community Health } \\
\text { Survey } 2003\end{array}$ & $\begin{array}{l}\text { Involvement in school sport } \\
\text { during adolescens was } \\
\text { significant predictor of lower } \\
\text { depression, perceiced stress, and } \\
\text { higher self-rated mental health }\end{array}$ \\
\hline 39) & Vella et al. (2015) & $\mathrm{N}=4042$ & $8-10(8.25)$ years & $\begin{array}{l}\text { Longitudinal } \\
\text { (2 years follow-up) }\end{array}$ & Sports participation & Psychological difficulties & $\begin{array}{l}\text { Parent-report version of Strength } \\
\text { and Difficulties (SDQ) }\end{array}$ & $\begin{array}{l}\text { Children who maintained } \\
\text { participation in sports had lower } \\
\text { rates of psychological difficulties } \\
\text { comapred with others (not } \\
\text { participation, commenced, } \\
\text { dropout) }\end{array}$ \\
\hline 41) & Vella et al. (2015) & $N=2785$ & $4-5$ to $12-13$ years & $\begin{array}{l}\text { Longitudinal } \\
\text { (8 years follow-up) }\end{array}$ & Sports participation & $\begin{array}{l}\text { Health-related QOL } \\
\text { (HRQOL) }\end{array}$ & $\begin{array}{l}\text { Parent report version of Pediatric } \\
\text { Quality of Life Scale (PedsQL) } \\
4.0 .\end{array}$ & $\begin{array}{l}\text { Sports partcipation is a } \\
\text { significant predictor of trajectory } \\
\text { of HRQOL during childhood }\end{array}$ \\
\hline 45) & Badura et al. (2015) & $\mathrm{N}=10483$ & $11,13,15$ years & Cross-sectional & $\begin{array}{l}\text { Organaized leisure-time } \\
\text { activities(OLTA) } \\
\text { - Inactive adolescents } \\
\text {-Team sports } \\
\text { - Individual sports } \\
\text { - Artist } \\
\text { - All-rounder }\end{array}$ & $\begin{array}{l}\text {-Life satisfaction } \\
\cdot \text {-Health complaints } \\
\text {-Physical health }\end{array}$ & $\begin{array}{l}\text {-Behaviour in School-aged } \\
\text { Children (HBSC) study }\end{array}$ & $\begin{array}{l}\text {-Organized activities done in } \\
\text { leisure time are associated with } \\
\text { better physical and mental health } \\
\text { among adolescents, and this } \\
\text { association is partly gender- and } \\
\text { age-specific } \\
\text { - While boys and older kids } \\
\text { might benefit more from } \\
\text { participating in team or } \\
\text { individual sports, participation } \\
\text { in art schools was associated } \\
\text { with better health outcomes in } \\
\text { girls and younger kids }\end{array}$ \\
\hline 44) & Sabiston et al. (2016) & $\mathrm{N}=860$ & 18 years & $\begin{array}{l}\text { Longitudinal } \\
\text { (3 yeas later) }\end{array}$ & $\begin{array}{l}\text { Sports paticipation } \\
\text { (Team sports vs. } \\
\text { individual sports) }\end{array}$ & Depressive symptoms & $\begin{array}{l}\text { Major Depression } \\
\text { Inventory(MDI) by Bech (2001) } \\
\text { Depressive symptom scale by } \\
\text { Kandel \& Davies (1982) }\end{array}$ & $\begin{array}{l}\text { Adolescents who consistently } \\
\text { participated in team sport during } \\
\text { high school reported lower } \\
\text { depression scores in early } \\
\text { adulthood }\end{array}$ \\
\hline 38) & McMahon et al. (2017) & $N=11072$ & 14.8 years & Cross-sectional & Sports participation & $\begin{array}{l}\text { - Depressive symptoms } \\
\text {-Anxiety symptoms } \\
\text { - Well-being }\end{array}$ & $\begin{array}{l}\cdot \text { - Beck Depression Inventory II } \\
\text { (BDI- I ) } \\
\text {-Zung Self-Rating Anxiety } \\
\text { Scale (SAS) } \\
\text {-Well-being Index (WHO-5) }\end{array}$ & $\begin{array}{l}\text { - More fequent } 60 \text { min MVPA } \\
\text { contributed to greater well-being } \\
\text { and lower levels of anxiety and } \\
\text { depressive symptoms among the } \\
\text { least active young people } \\
\text { - Sports participation more } \\
\text { confers an additional benefit } \\
\text { compared with recommended PA } \\
\text { alone }\end{array}$ \\
\hline
\end{tabular}

運動・スポーツのクラブ活動と喫煙・飲酒・薬物乱用と の関連について調査した報告がある ${ }^{51)}$ 。それによると， クラブ活動に参加していない高校生ほどタバコ, 酒, 大 麻の経験率が高く, さらに運動・スポーツとの関連をみ ると, 参加頻度が低い者ほど夕バコの経験率が高くなる
と報告している。だだし，酒と大麻については有意な関 係が認められていない ${ }^{51)}$ 。一方, 沖縄県の高校生を対象 に実施された調査では，学校課外活動（スポーツ以外の 活動も含む）への参加と喫煙や飲酒との間に負の関連が あったことを報告しているが，運動・スポーツに限った 
場合では，オッズ比に有意性は認められなかったことを 報告している ${ }^{52)}$. これらの研究はいずれも横断研究であ り, 組織的な運動・スポーツと非健康行動との関連につ いての明確な答えを導くのは難しい. また, 運動・スポー ツの継続的な参加によって自己統制力や忍耐力, 規律心 が高まることを前提とするならば，縦断的研究による知 見こそが重要となるであろう。そこで, Kwan $5^{53)}$ の縦 断的研究のみを対象としたシステマティックレビューが 参考になる。Table 5 は, Kwan ら ${ }^{53)}$ が対象とした論文 を飲酒と薬物に分けて好ましい関係（favorable），好ま しくない関係（unfavorable）および関連なし（null）に 分類してまとめたものである。 その結果, 飲酒について は全体の論文数に対して unfavorable として評価された 論文数の割合は $82.4 \%$ 注1) となり, もはや組織的なスポー ツ・運動に参加していることが飲酒に限定した非健康行 動には抑止力とならないどころか, 助長してしまう可能 性が窅い知れる（Table 5-A）。一方, 薬物については, favorableに該当する論文数の割合が $41.7 \%$ 注1)であり， 抑止力としての効果が十分にあるとは判断できないまで も，運動・スポーツが引き金になっているということは なさそうである (Table 5-B). だだし，これらの知見に は性差 $^{54,55)}$, 人種差 ${ }^{56,57)}$, 社会的経済状況 ${ }^{58)}$, 運動・スポー ツの種目特性 ${ }^{59)}$ によって結果が異なるケースが含まれて いることにも十分留意すべきある。

\section{非組織的な運動遊びとヘルスアウトカム}

運動遊びの定義は簡単でないが, 一般的には大人の管 理下にない子どもの自主的活動が前提である. Sandseter ${ }^{60-62)}$ は，危険な運動遊びを 6つのカテゴリに分類し, その危険性を定義づけしている。ささらに, 危険な運動遊 びが発生しやすい環境において10の特徵を提示している (Table 6). そしてBrussoni ら ${ }^{63)}$ は, これらの危険な運 動遊びとへルスアウトカムとの関連を報告した研究につ いてまとめている。 このレビュー論文の中で扱われてい るアウトカムは, 日常生活全体の身体活動量やMVPA, 骨折などの外傷, 危険な運動遊びを実施している際の身 体活動量, 社会スキル, 非社会的行動である。主に社会 スキルと非社会的行動に関する内容に注目すると, いず れのアウトカムにおいてもエビデンスの質については, 横断的観察研究によるため「とても低い」という評価と なっているものの, 運動遊びとの関連を報告した貴重な 報告であると思われる。社会スキルの側面への効果とし て, 親から「子どもの単独での外出」を認められている

注1) Kwan らの引用論文総数に対する 3 つの結論（favorable, unfavorable, null）の割合（\%）を示す。ただし，1つ論 文内で対象特性（人種, 性, 競技種目) に応じて 2 つの結 論（例えば, white: unfavorable, black: favorable）を明示 しているケースが複数論文あるため，3つの結論の割合

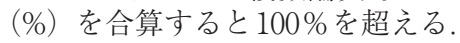

子どもほど，親戚や親の友達の子どもではない自身の友 達との交友が盛んであり, 逆に, 親からの活動を制限さ れている子どもは, 近隣や学校の友達との交友が少ない ことが指摘されている ${ }^{64)}$.また, 2 編の研究報告 ${ }^{65.66)}$ が, 屋外で「相撲」「プロレス」「闘いごっこ」「追いかけっ こ」等を行うことを指す Rough and Tumble Play (RTP) を好む子どもは, 人間関係で生じる認知的問題への解決 力に優れて抢り, さらに 3 編の研究報告 ${ }^{66-68)}$ が, RTP を好む子どもが周囲から好意的な存在として認められて いると述べている，その一方で，女子の評価が含まれる 場合には, 男子の RTP と周囲からの人気度との関連や, RTP と教師が評価する社会的能力との関連には無関係あ るいはネガティブな関連があったと報告する例もあり, 分析する対象者によって知見が異なることを報告してい る.さらに, RTP と他者への攻撃的なふるまいに抏いて は，周囲から人気のある子どもは，そのようなふるまい がみられない傾向にあることを報告しているが，逆に， 周囲からの人気が低い子どもの場合では, RTP と攻撃的 ふるまいに関連があるとしている，また，RTPをさらに 「追いかけっこ」と「闘いごっこ」に分類すると, 後者 の方が攻撃的ふるまいの発生がやや多くなる可能性を別 の先行研究から椝い知ることができる ${ }^{69)}$.

わずか 2 つの研究成果からではあるが, 子どもの外遊 びの環境について，例えば遊具などの活動に制約がある 環境よりも，開放的な冒険広場の方が，子どもは社交的 で, 創造性に富み, より活発に行動する可能性が報告さ れている ${ }^{70,71)}$.そしてBrussoni ら ${ }^{63)}$ のレビューを基に, 2015年にカナダのブリティッシュコロンビア大学の研 究者が中心となって, 『活発な外遊び』に関する意見報 告書 (声明) を発表している ${ }^{72)}$. ここでは身体的, 精神的, 社会的恩恵に関する11の提言を示しており，その中に独 立心や対人関係能力 ${ }^{64,73,74)}$, 自己統制力 ${ }^{75,76)}$, 自己効力 感 ${ }^{77)}$, 交渉力ゃ健康行動 ${ }^{78)}$, 問題解決力や回復力 ${ }^{79,80)}$, 創造的思考力 ${ }^{81)}$ などの良好なメンタルヘルスと社会スキ ルの獲得に寄与する点が述べられている。 また, 子ども から自由な外遊びを奪うことは, 社会的孤立感が高まり, 幸福感が低下することも指摘されている ${ }^{82)}$.

Maas ${ }^{83)}$ は, 数量化した居住周辺の自然環境と抑う つや不安との間には良好な関係性があることを報告して いる.またMcCurdy ${ }^{84)}$ の自然環境下での暮らしや身体 活動の効果についてまとめた総説論文では, 窓から見え る樹木や草木, そして室内植物に囲まれて暮らす子ども ほど, 引っ越しなどのライフイベントによるストレスの 程度も小さいことを報告している ${ }^{85)}$. さらに自然環境に よる attention-deficit hyperactivity disorder (ADHD) への好ましい効果について 7 編の論文が引用されてい る $^{86-92)}$.このような自然環境下での自発的な遊びが子ど もの心身の健康においていかに重要であるかについて 
Table 5-A. Overview of findings on relationships between sports participation and alcohol in a review paper ${ }^{53)}$

\begin{tabular}{|c|c|c|c|c|c|}
\hline Author & Sample & Favorable & Unfavorable & Null & Special note \\
\hline Aaron et al. (1995) & $\begin{array}{l}\mathrm{N}=405 \\
12 \text {-to- } 16 \text { year-old at baseline } \\
1 \& 4 \text { years Follow-up from } \\
\text { basline }\end{array}$ & & $\checkmark$ & & $\begin{array}{l}\text { Males participating in athletics were more likely to initiate } \\
\text { alcohol usage at the } 3 \text { year follow-up than male that did not }\end{array}$ \\
\hline Eccles \& Barber (1999) & $\begin{array}{l}N=1256 \\
\text { Grades } 10 \& 12\end{array}$ & & $\checkmark$ & & \\
\hline Barber et al. $(2001)^{54)}$ & $\begin{array}{l}\mathrm{N}=900 \\
\text { Aged } 16 \text { at baseline } \\
\text { There were } 3 \text { subsequent } \\
\text { follow-up assessments } 2,5, \& \\
9 \text { years later. }\end{array}$ & & $\checkmark$ & & $\begin{array}{l}\text { Significant Interaction (Sex } \times \text { sports) } \\
\text { A significant gender by sport by time interaction suggests that } \\
\text { female athletes increased their frequency of alcohol use at a } \\
\text { faster rate than non-athlete females, while male athletes had a } \\
\text { slower rate of increase compared to male nonathletes }\end{array}$ \\
\hline Crossnoe $(2002)^{55)}$ & $\begin{array}{l}\mathrm{N}=2651 \\
\text { Three years follow-up during } \\
\text { high school }\end{array}$ & & ※ & $\checkmark$ & $\begin{array}{l}\text { ※ It means favorable in female athletes compared with } \\
\text { female non-athletes }\end{array}$ \\
\hline Eitle et al. $(2003)^{56)}$ & $\begin{array}{l}\mathrm{N}=1230 \\
\text { Aged } 18 \text { at baseline and } \\
\text { reassessed } 8 \text { years later }\end{array}$ & & $\checkmark$ & & Including effect of races (White and Caucasian athletes only) \\
\hline Miller et al. (2003) & $\begin{array}{l}\mathrm{N}=611 \\
\text { Aged } 14 \text { at baseline } \\
\text { Follow-up } 6 \text { years later }\end{array}$ & & & $\checkmark$ & $\begin{array}{l}\text { The frequency of sport participation was not related to } \\
\text { frequency of drinking and binge drinking }\end{array}$ \\
\hline Darling (2005) & $\mathrm{N}=3427$ & & & $\checkmark$ & \\
\hline Dawkins et al. $(2006)^{57)}$ & $\begin{array}{l}N=1052 \\
\text { Grade } 10 \& 12\end{array}$ & 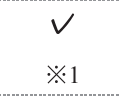 & 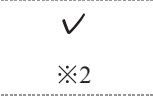 & & $\begin{array}{l}※ 1 \text { The unfavorable association is among white athletes. } \\
※ 2 \text { sport participation was negatively associated among black } \\
\text { female athletes }\end{array}$ \\
\hline Fredricks \& Eccles (2006) & $\begin{array}{l}\mathrm{N}=508 \\
\text { Grades } 7,8,10 \\
\text { Two follow-up periods }\end{array}$ & & $\checkmark$ & & $\begin{array}{l}\text { There was a positive association between sport participation } \\
\text { (years in sports) and alcohol use during students' final year of } \\
\text { high school }\end{array}$ \\
\hline Hoffman $(2006)^{58)}$ & $\begin{array}{l}\mathrm{N}=9893 \\
\text { Grade } 10 \text {, and they were } \\
\text { reassessed when in grade } 12\end{array}$ & & $\checkmark$ & & $\begin{array}{l}\text { There was a positive relationship between athletic activities } \\
\text { and increases in alcohol uses during high school for both } \\
\text { males and females. The association for male is stronger } \\
\text { among school in lower socio-economic status (SES). } \\
\text { Whereas, this association for female is adverse }\end{array}$ \\
\hline Fauth et al. (2007) & $\begin{array}{l}\mathrm{N}=1315 \\
\text { Nine and } 12 \text { years old } \\
\text { Followed over a } 6 \text {-year period }\end{array}$ & & $\checkmark$ & & $\begin{array}{l}\text { Sport participation at baseline was associated with greater } \\
\text { substance use at 3-and } 5 \text {-year follow-ups, and associated with } \\
\text { greater and substance use over time }\end{array}$ \\
\hline Peck et al. (2008) & $\begin{array}{l}\mathrm{N}=1000 \\
\text { Twelve years old } \\
\text { Three follow-ups 4-years apart }\end{array}$ & & $\checkmark$ & & $\begin{array}{l}\text { The positive relationship was stronger among sport } \\
\text { participants who were also above average users of alcohol and } \\
\text { drugs at age } 18\end{array}$ \\
\hline Wichstrom \& Wichstrom (2009) & $\begin{array}{l}\mathrm{N}=3251 \\
\text { Aged } 13-\text { to-19 at baseline, and } \\
\text { reassessed 2, 5, and } 7 \text { years } \\
\text { later }\end{array}$ & $\checkmark$ & $\checkmark$ & & $\begin{array}{l}\text { Sport participation predicted growth in alcohol intoxication. } \\
\text { ※ Endurance sports had a lower growth in alcohol, whereas } \\
\text { initial team sports had an increased growth in alcohol } \\
\text { ntoxication }\end{array}$ \\
\hline May et al. (2010) & $\begin{array}{l}\mathrm{N}=8721 \\
\text { Aaged } 12 \text {-to-18 at baseline, } \\
\text { and two follow-ups 3-years } \\
\text { apart }\end{array}$ & $\begin{array}{l}\vee \\
※ 1\end{array}$ & $\begin{array}{l}\vee \\
※ 2\end{array}$ & & $\begin{array}{l}\text { ※1 Participation in sports with participation in other school } \\
\text { activities showed significantly less accelerations in alcohol- } \\
\text { related behaviors compared to sport participation alone } \\
\text { ※2 Participation in sports alone was a significant predictor of } \\
\text { growth in alcohol-related behaviors over the 6-years. }\end{array}$ \\
\hline Terry-McElrath \& O'Malley (2011) & $\begin{array}{l}\mathrm{N}=11,741 \\
\text { Age } 18 \text { at baseline, and } \\
\text { ressessed } 4 \text { times every } 2 \text { years }\end{array}$ & & $\checkmark$ & 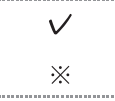 & $\begin{array}{l}\text { ※ Sport participation was not significantly related to changes } \\
\text { to changes in alcohol use over time }\end{array}$ \\
\hline Mahoney \& Vest (2012) & $\begin{array}{l}\mathrm{N}=1115 \\
\text { Twelve to } 18 \text { years at baseline, } \\
\text { and they were reassessed when } \\
\text { they were } 18 \text {-to- } 24\end{array}$ & & & $\checkmark$ & \\
\hline \multirow[t]{2}{*}{ Sher \& Rutledge (2007) } & $\begin{array}{l}\mathrm{N}=3720 \\
\text { Freshman students first } \\
\text { entering college and followed- } \\
\text { up after first semester }\end{array}$ & & $\checkmark$ & & $\begin{array}{l}\text { There were significant increases in heavy drinking from pre- } \\
\text { college to first semester of college }\end{array}$ \\
\hline & & $17.6 \% *$ & $82.4 \% *$ & $29.4 \%$ * & \\
\hline
\end{tabular}

* These values show the percentage of the number of findings to total number of previous studies. Five studies of all include two findings

最近研究によっても支持されている ${ }^{93)}$ 。この点に関連 して，座位型TVゲーム時間（sedentary video games: SVGs）をアクティブ型TVゲーム（active video games: AVGs) や運動外遊び (active outdoor play：AOP) 時間 に置き換えた場合に, メンタルヘルス（情緒的問題, 生 活の満足度, 社会的ふるまい) に問題を抱える子どもの
発生率をシミュレーションした横断研究がある ${ }^{94)}$ 。これ によると，1 日あたり 1 時間のSVGsをAVGsに置き換 えることで情緒的問題を抱える子どもの割合が $6 \%$ 減少 し，生活への満足感が充たされる，あるいは社会的ふ るまいが良好である子どもの割合がそれぞれ $4 \%$ および 13\%増加することを報告している。ただし，1日あたり 
Table 5-B. Overview of findings on relationships between sports participation and drug use in a review study ${ }^{53)}$

\begin{tabular}{|c|c|c|c|c|c|}
\hline Authors & Sample & Favorable & Unfavorable & Null & Special note \\
\hline Aaron et al. (1995) & $\begin{array}{l}\mathrm{N}=405 \\
12-16 \text { year-old at baseline } \\
\text { One \& } 4 \text { years Follow-up from } \\
\text { basline }\end{array}$ & & & $\checkmark$ & \\
\hline Eccles \& Barber (1999) & $\begin{array}{l}\mathrm{N}=1256 \\
\text { Grades } 10 \& 12\end{array}$ & & $\checkmark$ & & \\
\hline Barber et al. $(2001)^{54)}$ & $\begin{array}{l}\mathrm{N}=900 \\
\text { Aged } 16 \text { at baseline } \\
\text { There were } 3 \text { subsequent } \\
\text { follow-up assessments 2, 5, \& } \\
9 \text { years later }\end{array}$ & $\checkmark$ & & & $\begin{array}{l}\text { Athletes reported increases in marijuana use throughout high } \\
\text { school but their rates stabilized in their early adulthood. Non- } \\
\text { athletes had similar increases throughout high school, and } \\
\text { their } \\
\text { stabilization rates occurred later in adulthood }\end{array}$ \\
\hline Crossnoe $(2002)^{55)}$ & $\begin{array}{l}\mathrm{N}=2651 \\
\text { Three years follow-up during } \\
\text { high school }\end{array}$ & & & $\checkmark$ & $\begin{array}{l}\text { Regardless of athletic status, female had lower growth in } \\
\text { illicit drug use and other drugs }\end{array}$ \\
\hline Eitle et al. $(2003)^{56)}$ & $\begin{array}{l}\mathrm{N}=1230 \\
\text { Aged } 18 \text { at baseline and } \\
\text { reassessed } 8 \text { years later }\end{array}$ & $\checkmark$ & & & $\begin{array}{l}\text { There was a negative association between sport participation } \\
\text { and illegal drug use among African Americans when they } \\
\text { reached early adulthood }\end{array}$ \\
\hline Darling (2005) & $\mathrm{N}=3427$ & $\checkmark$ & & & $\begin{array}{l}\text { More years involved in extracurricular activities, including } \\
\text { intramural sports, were significantly associated lower use in } \\
\text { marijuana use and other drugs }\end{array}$ \\
\hline Dawkins et al. $(2006)^{57)}$ & $\begin{array}{l}\mathrm{N}=1052 \\
\text { Grade } 10 \& 12\end{array}$ & $\checkmark$ & & & \\
\hline Fauth et al. (2007) & $\begin{array}{l}\mathrm{N}=1315 \\
\text { Nine and } 12 \text { year-old } \\
\text { Followed over a } 6 \text {-year period }\end{array}$ & & $\checkmark$ & & $\begin{array}{l}\text { Sport participation at baseline was associated with greater } \\
\text { substance use at } 3 \text { - and } 5 \text {-year follow-ups, and associated with } \\
\text { greater and substance use over time }\end{array}$ \\
\hline Peck et al. (2008) & $\begin{array}{l}\mathrm{N}=1000 \\
\text { Twelve years old } \\
\text { Three follow-ups 4-years apart }\end{array}$ & & $\checkmark$ & & $\begin{array}{l}\text { The positive relationship was stronger among sport } \\
\text { participants who were also above average users of alcohol and } \\
\text { drugs at age } 18\end{array}$ \\
\hline Wichstrom \& Wichstrom (2009) ${ }^{59)}$ & $\begin{array}{l}\mathrm{N}=3251 \\
\text { Aged } 13 \text {-to-19 at baseline, and } \\
\text { reassessed 2, 5, and } 7 \text { years } \\
\text { later }\end{array}$ & $\begin{array}{l}\vee \\
※\end{array}$ & & & ※ Sports participation had an reduced growth in cannabis use \\
\hline Terry-McElrath \& O'Malley (2011) & $\begin{array}{l}\mathrm{N}=11,741 \\
\text { Age } 18 \text { at baseline, and } \\
\text { ressessed } 4 \text { times every } 2 \text { years }\end{array}$ & & $\checkmark$ & $\checkmark$ & $\begin{array}{l}\text { ※ Sport participation was not significantly related to changes } \\
\text { to changes in marijuana, or other illicit drug use over time }\end{array}$ \\
\hline Mahoney \& Vest (2012) & $\begin{array}{l}\mathrm{N}=1115 \\
\text { Twelve to } 18 \text { years at baseline, } \\
\text { and they were reassessed when } \\
\text { they were } 18 \text {-to- } 24\end{array}$ & & & $\checkmark$ & \\
\hline
\end{tabular}

${ }^{*}$ These values show the percentage of the number of findings to total number of previous studies. One study includes two findings

1 時間のAOPをAVGsに置き換えると, 情緒的問題で は $7 \%$ 増加し, 生活の満足度, 社会的ふるまいではそれ ぞれ $3 \%$ と $6 \%$ の減少がみられたと報告しており, 自然 環境下での運動遊びの重要性が示唆されている.

以上のことから，運動遊びの形態は多様性を有してお り定義づけが難しいものの，自然環境がもたらす恩恵に 加え, 大人の管理下にない環境で主体的に体を動かすこ とによる相乗効果が, 精神的ストレスの軽減や社会スキ ルの獲得に大きく寄与していることが考えられる。これ
は我々が想像する以上に，運動遊びが子どもの心理，社 会的健康の増進に有効である可能性が高く, 運動・スポー ツに目が向けられがちな現代社会において, 改めて子ど もの屋外での運動遊び環境の整備や政策を見直す必要が あるのかもしれない。児童期，青少年期の体を動かした 体験值，すなわち身体活動の量的，質的側面が成人以降 の運動習慣や身体活動にトラッキングすること ${ }^{95,96)}$ を踏 まえると, 運動遊びを対象としたさらなる研究の蓄積が 求められよう. 
Table 6. Classification of risky outdoor play behaviors in previous studies ${ }^{60-62)}$

\begin{tabular}{|c|c|c|}
\hline Risky play categories & Definition & Examples \\
\hline Great heights & Danger of injury from falling & $\begin{array}{l}\text { Climbing/jumping from surfaces, balancing/playing on high } \\
\text { objects (e.g., playground equipment), hanging/swinging at } \\
\text { great heights }\end{array}$ \\
\hline High speed & $\begin{array}{l}\text { Uncontrolled speed and pace that can lead to } \\
\text { collision with something (or someone) }\end{array}$ & Swinging at high speed \\
\hline Dangerous tools & Can lead to injuries and wounds & $\begin{array}{l}\text { Cutting tools (e.g., knives, saws, or axes), strangling tools } \\
\text { (e.g., ropes) }\end{array}$ \\
\hline Dangerous elements & Where children can fall into or from something & Cliffs, water, fire pits, trees \\
\hline Rough and Tumble Play & Where children can be harmed & Wrestling or play fighting with other children or parents \\
\hline Disappera / get lost & $\begin{array}{l}\text { Where children can disappear from the supervision } \\
\text { of adults or get lost alone }\end{array}$ & $\begin{array}{l}\text { Exploring alone, playing alone in unfamiliar environments, } \\
\text { general independent mobility, or unsupervised play }\end{array}$ \\
\hline
\end{tabular}

\section{まとめ}

本研究は, 活動強度, 組織的運動・スポーツ, 非組織 的運動遊びの視点から身体活動を捉え, メンタルヘルス， ライフスキルを含む社会スキル，健康行動などのへルス アウトカムに関連する恩恵についての知見を整理するこ とを目的とした。

その結果, 運動・スポーツによる恩恵として, 特に MVPAなどの強度的側面からみた効果には, 介入研究に みられるように短期的な効果として抑うつ症状の改善や 不安感の減少がみられた。さらに，総身体活動量が多い ことによる効果とする知見も複数あり，強度と共に量的 な側面にも着目する必要がある。

また，組織的運動・スポーツへの所属の有無という観 点からは, メンタルヘルスの増進や社会スキルの獲得に 寄与するという知見が大半であるが，それはトップアス リートを対象とした場合を除いてである。

非健康行動においては，薬物への抑止力となる可能性 を含んでいるが, 飲酒においては運動・スポーツのコミュ ニティへの所属がむしろ助長している可能性もある。た だし, 性差, 人種差, 社会的経済状況, 運動・スポーツ の種目特性を考慮すると結論は一様でない。また非組織 的な運動遊びの視点からは, 自然環境がもたらす恩恵に 加え, 大人の管理下にない環境で主体的に体を動かすこ とが相乗効果となり, 精神的ストレスの軽減や社会スキ ルの獲得に大きく寄与していることが明らかとなった。

まとめると，子どもにおける運動・スポーツ活動には， 同じ目的を共有した仲間の集まりであるコミュニティが 形成されていることが重要であり，そこにある一定以上 の量や強度が伴った身体活動が付加されることで，他の 文化芸術活動などの活動でもたらされる健康への恩恵以 上のものが期待できるのかもしれない。また，非組織的 な運動遊びは，我々が想像する以上に子どもの心理，社
会的健康の増進に有効となる可能性が示された。我が国 では東京オリンピックを目前に運動・スポーツへの関心 が高まっているものの, 地域間の所得格差 ${ }^{97)}$ や組織的な 運動・スポーツを享受する機会の平等性という点では大 きな課題を抱えている ${ }^{98)}$ ，その点では，子どもの運動遊 びを促進するための環境の再整備や新たな政策を提案す ることは，波及効果の視点からみても有効といえるのか もしれない，例えば，都市計画法に基づき首都圈近郊の街 区公園は年々増加している一方で，遊び場として利用し ている子どもの割合は 5 割程度に留まっており，その利 用頻度も週 1 ～ 2 回程度であることが報告されている ${ }^{99)}$. その原因には，利用する子どもが求める遊び場と実際の 公園環境には大きな隔たりのあることが考えられる ${ }^{99)}$. そのため, 屋外での運動遊びの促進に向けた具体的な提 案をするならば，既存の街区公園のリノベーションなど は有効な環境整備の 1 つと考えられよう100)。

最後に，本研究で引用した研究成果のエビデンスレベ ルは必ずしも高いとはいい切れず，また国内の研究成果 も限られているため, 今後はアウトカムに対して運動・ スポーツの効果について体系的な組織へ所属する意義と そこである一定以上の運動強度を実施する意義を区別し た追跡調査や対象者特性を踏まえた介入研究による成果 の蓄積と整理が必要である。

利益相反自己申告：申告すべきものはなし

\section{謝 辞}

本研究は平成 25 年度日本体力医学会プロジェクト研究, な らびにJSPS科研費JP15H03108の助成を受けたものである.

\section{引用文献}

1）日本学術会議. 日本の子どものへルスプロモーション pp12-13, 2010. 
2) Ortega FB, Ruiz JR, Castillo MJ, Sjöström M. Physical fitness in childhood and adolescence: a powerful marker of health. Int J Obes (Lond) 32: 1-11, 2008.

3) Poitras VJ, Gray CE, Borghese MM, Carson V, Chaput JP, Janssen I, Katzmarzyk PT, Pate RR, Connor Gorber S, Kho ME, Sampson M, Tremblay MS. Systematic review of the relationships between objectively measured physical activity and health indicators in school-aged children and youth. Appl Physiol Nutr Metab 41: S197-239, 2016.

4) Pate RR, Trost SG, Levin S, Dowda M. Sports participation and health-related behaviors among US youth. Arch Pediatr Adolesc Med 154: 904-911, 2000.

5) Bangsbo J, Krustrup P, Duda J, Hillman C, Andersen LB, Weiss M, Williams CA, Lintunen T, Green K, Hansen PR, Naylor PJ, Ericsson I, Nielsen G, Froberg K, Bugge A, Lundbye-Jensen J, Schipperijn J, Dagkas S, Agergaard S, von Seelen J, Østergaard C, Skovgaard T, Busch H, Elbe AM. The Copenhagen Consensus Conference 2016: children, youth, and physical activity in schools and during leisure time. Br J Sports Med 50: 1177-1178, 2016.

6）大島秀武, 引原有輝, 笠次良爾, 村瀬訓生, 石井好二郎： 思春期前期向けに改変した日本語版IPAQによる中高 強度身体活動量評価の妥当性, 体力科学, 66: 427-436, 2017.

7) van Sluijs EM, McMinn AM, Griffin SJ. Effectiveness of interventions to promote physical activity in children and adolescents: systematic review of controlled trials. Br J Sports Med 42: 653-657, 2008.

8) Metcalf B, Henley W, Wilkin T. Effectiveness of intervention on physical activity of children: systematic review and meta-analysis of controlled trials with objectively measured outcomes (EarlyBird 54). BMJ 345: e5888, 2012.

9) Strauss RS, Rodzilsky D, Burack G, Colin M. Psychosocial correlates of physical activity in healthy children. Arch Pediatr Adolesc Med 155: 897-902, 2001.

10) Parfitt G, Pavey T, Rowlands AV. Children's physical activity and psychological health: the relevance of intensity. Acta Paediatr 98: 1037-1043, 2009.

11) Standage M, Gillison FB, Ntoumanis N, Treasure DC. Predicting students' physical activity and healthrelated well-being: a prospective crossdomain investigation of motivation across school physical education and exercise settings. J Sport Exerc Psychol 34: 37-60, 2012.

12) Herman KM, Sabiston CM, Tremblay A, Paradis G. Self-rated health in children at risk for obesity: associations of physical activity, sedentary behavior, and BMI. J Phys Act Health 11: 543-552, 2014.

13) Johnson CC, Murray DM, Elder JP, Jobe JB, Dunn AL, Kubik M, Voorhees C, Schachter K. Depressive symptoms and physical activity in adolescent girls. Med Sci Sports Exerc 40: 818-826, 2008.

14) Sebire SJ, Jago R, Fox KR, Page AS, Brockman R, Thompson JL. Associations between children's social functioning and physical activity participation are not mediated by social acceptance: a cross-sectional study. Int J Behav Nutr Phys Act 8: 106, 2011.

15) Wiles NJ, Haase AM, Lawlor DA, Ness A, Lewis G. Physical activity and depression in adolescents: crosssectional findings from the ALSPAC cohort. Soc PSychiatry Psychiatr Epidemiol 47: 1023-1033, 2012.

16) Young D, Saksvig BI, Wu TT, Zook K, Li X, Champaloux S, Grieser M, Lee S, Treuth MS. Multilevel correlates of physical activity for early, mid, and late adolescent girls. J Phys Act Health 11: 950-960, 2014.

17) Kriemler S, Zahner L, Schindler C, Meyer U, Hartmann T, Hebestreit H, Brunner-La Rocca HP, van Mechelen W, Puder JJ. Effect of school based physical activity programme (KISS) on fitness and adiposity in primary schoolchildren: cluster randomised controlled trial. BMJ 340: c785, 2010.

18) Toseeb U, Brage S, Corder K, Dunn VJ, Jones PB, Owens M, St Clair MC, van Sluijs EM, Goodyer IM. Exercise and depressive symptoms in adolescents: a longitudinal cohort study. JAMA Pediatr 168: 10931100, 2014.

19) Guyatt G, Oxman AD, Akl EA, Kunz R, Vist G, Brozek J, Norris S, Falck-Ytter Y, Glasziou P, DeBeer H, Jaeschke R, Rind D, Meerpohl J, Dahm P, Schünemann HJ. GRADE guidelines: 1. Introduction-GRADE evidence profiles and summary of findings tables. $J$ Clin Epidemiol 64: 383-394, 2011.

20) Langguth N, Schmid J, Gawrilow C, Stadler G. Within-person link between depressed affect and moderate-to-vigorous physical activity in adolescence: an intensive longitudinal approach. Appl Psychol Health Well Being 8: 44-63, 2016.

21) Tymms PB, Curtis SE, Routen AC, Thomson KH, Bolden DS, Bock S, Dunn CE, Cooper AR, Elliott JG, Moore HJ, Summerbell CD, Tiffin PA, Kasim AS. Clustered randomised controlled trial of two education interventions designed to increase physical activity and well-being of secondary school students: the MOVE Project. BMJ Open 6: e009318, 2016.

22) Wang JJ, Baranowski T, Lau PW, Chen TA, Zhang SG. Psychological correlates of self-reported and objectively measured physical activity among Chinese children-psychological correlates of PA. Int J Environ Res Public Health 13: e1006, 2016.

23) Zahl T, Steinsbekk S, Wichstrøm L. Physical activity, sedentary behavior, and symptoms of major depression in middle childhood. Pediatrics 139: e20161711, 2017.

24) Biddle SJ and Asare M. Physical activity and mental health in children and adolescents: a review of reviews. Br J Sports Med 45: 886-895, 2011.

25) Calfas KJ and Taylor WC. Effects of physical activity on psychological variables in adolescents. Pediatr $E_{X}$ erc Sci 6: 406-423, 1994.

26) Craft LL and Landers DM. The effect of exercise on clinical depression and depression resulting from 
mental illness: A meta-analysis. J Sport Exerc Psychol 20: 339-357, 1998.

27) Wipfli BM, Rethorst CD, Landers DM. The anxiolytic effects of exercise: a meta-analysis of randomized trials and dose-response analysis. J Sport Exerc Psychol 30: 392-410, 2008.

28) Larun L, Nordheim LV, Ekeland E, Hagen KB, Heian F. Exercise in prevention and treatment of anxiety and depression among children and young people. Cochrane Database Syst Rev 19: CD004691, 2006.

29) Ekeland E, Heian F, Hagen KB, Abbott J, Nordheim L. Exercise to improve self-esteem in children and young people. Cochrane Database Syst Rev: CD003683, 2004.

30）川勝佐希, 笠次良爾, 國土将平, 石井好二郎：質問紙 による中学生期における身体活動と健康関連 QOL お よび抑うつ傾向の実態調査, 発育発達研究, 62: 75-86, 2014.

31）川勝佐希, 國土将平, 森田憲輝, 鈴木和弘, 渡邊將司, 笠 次良爾, 上地広昭, 長野真弓, 山津幸司, 堤 公一, 辻延 浩, 久米大祐, 石井好二郎 : 大規模調査から確認された 思春期前期の子どもの身体活動とメンタルヘルス, 体 力科学, 66: 70, 2017.

32）永松俊哉：青年期におけるメンタルヘルスと運動・又 ポーツ活動の関係, 体力科学, 65: 375-381, 2016.

33) Eime RM, Young JA, Harvey JT, Charity MJ, Payne WR. A systematic review of the psychological and social benefits of participation in sport for children and adolescents: informing development of a conceptual model of health through sport. Int J Behav Nutr Phys Act 10: 98, 2013.

34) Brunet J, Sabiston CM, Chaiton M, Barnett TA, O'Loughlin E, Low NC, O'Loughlin JL. The association between past and current physical activity and depressive symptoms in young adults: a 10-year prospective study. Ann Epidemiol 23: 25-30, 2013.

35) Brown DR, Galuska DA, Zhang J, Eaton DK, Fulton JE, Lowry R, Maynard LM. Psychobiology and behavioral strategies. physical activity, sport participation, and suicidal behavior: U.S. high school students. Med Sci Sports Exerc 39: 2248-2257, 2007.

36) Taliaferro LA, Rienzo BA, Miller MD, Pigg RM Jr, Dodd VJ. High school youth and suicide risk: exploring protection afforded through physical activity and sport participation. J Sch Health 78: 545-553, 2008.

37) Guèvremont A, Findlay L, Kohen D. Organized extracurricular activities: are in-school and out-of-school activities associated with different outcomes for Canadian youth? J Sch Health 84: 317-325, 2014.

38) McMahon EM, Corcoran P, O'Regan G, Keeley H, Cannon M, Carli V, Wasserman C, Hadlaczky G, Sarchiapone M, Apter A, Balazs J, Balint M, Bobes J, Brunner R, Cozman D, Haring C, Iosue M, Kaess M, Kahn JP, Nemes B, Podlogar T, Poštuvan V, Sáiz P, Sisask M, Tubiana A, Värnik P, Hoven CW, Wasserman D. Physical activity in European adolescents and associations with anxiety, depression and well-being.
Eur Child Adolesc Psychiatry 26: 111-122, 2017.

39) Vella SA, Cliff DP, Magee CA, Okely AD. Associations between sports participation and psychological difficulties during childhood: a two-year follow up. $J$ Sci Med Sport 18: 304-309, 2015.

40) Vella SA, Cliff DP, Magee CA, Okely AD. Sports participation and parent-reported health-related quality of life in children: longitudinal associations. $J$ Pediatr 164: 1469-1474, 2014.

41) Vella SA, Magee CA, Cliff DP. Trajectories and Predictors of Health-Related Quality of Life during Childhood. J Pediatr 167: 422-427, 2015.

42) Sabiston CM, O'Loughlin E, Brunet J, Chaiton M, Low NC, Barnett T, O'Loughlin J. Linking depression symptom trajectories in adolescence to physical activity and team sports participation in young adults. Prev Med 56: 95-98, 2013.

43) Jewett R, Sabiston CM, Brunet J, O'Loughlin EK, Scarapicchia T, O'Loughlin J. School sport participation during adolescence and mental health in early adulthood. J Adolesc Health 55: 640-644, 2014.

44) Sabiston CM, Jewett R, Ashdown-Franks G, Belanger M, Brunet J, O'Loughlin E, O'Loughlin J. Number of years of team and individual sport participation during adolescence and depressive symptoms in early adulthood. J Sport Exerc Psychol 38: 105-110, 2016.

45) Badura P, Geckova AM, Sigmundova D, van Dijk JP, Reijneveld SA. When children play, they feel better: organized activity participation and health in adolescents. BMC Public Health 15: 1090, 2015.

46) Piché G, Fitzpatrick C, Pagani LS. Associations between extracurricular activity and self-regulation: a longitudinal study from 5 to 10 years of age. Am J Health Promot 30: e32-40, 2015.

47) Ekelund RC, Gould D. Emotional stress anxiety in the child and adolescent athlete. In: The Young Athlete (Hebestreit H, Bar-Or O, eds), Blackwell Publishing Ltd, MA, USA, 319-334, 2008.

48) Merkel DL. Youth sport: positive and negative impact on young athletes. Open Access J Sports Med 4: 151160, 2013.

49) O'Loughlin J, Karp I, Koulis T, Paradis G, Difranza J. Determinants of first puff and daily cigarette smoking in adolescents. Am J Epidemiol 170: 585-597, 2009.

50) Azagba S, Langille D, Asbridge M. The consumption of alcohol mixed with energy drinks: prevalence and key correlates among Canadian high school students. CMAJ Open 1: E19-26, 2013.

51）三好美浩, 勝野眞吾, 和田 清 : 全国高校生におけるク ラブ活動および運動と喫煙・飲酒・薬物乱用との関連 - 2004, 2006, 2009年JSPAD 調査のボンド・サンプル の結果 -, 日本アルコール・薬物医学会雑誌, 48: 426444, 2013.

52) Takakura M. Relations of participation in organized activities to smoking and drinking among Japanese youth: contextual effects of structural social capital in high school. Int J Public Health 60: 679-689, 2015. 
53) Kwan M, Bobko S, Faulkner G, Donnelly P, Cairney J. Sport participation and alcohol and illicit drug use in adolescents and young adults: a systematic review of longitudinal studies. Addict Behav 39: 497-506, 2014.

54) Barber BL, Eccles JS, Stone MR. Whatever happened to the jocks, the brain, and the princess? young adult pathways linked to adolescent activity involvement and social identity. J Adolesc Res 16: 429-455, 2001.

55) Crossnoe R. Academic and health-related trajectories in adolescence: the intersection of gender and athletics. J Health Soc Behav 43: 317-335, 2002.

56) Eitle D, Turner JR, Eitle TM. The deterrence hypothesis reexamined: sport participation and substance use among young adults. J Drug Issues 33: 193-221, 2003.

57) Dawkins MP, Williams MM, and Guilbault M. Participation in school sports: Risk or protective factor for drug use among black and white students? J Negro Educ 75: 25-33, 2006.

58) Hoffmann JP. Extracurricular activities, athletic participation, and adolescent alcohol use: gender-differentiated and school-contextual effects. $J$ Health Soc Behav 47: 275-290, 2006.

59) Wichstrom $\mathrm{T}$ and Wichstrom L. Does sport participation during adolescence prevent later alcohol, tobacco, and cannabis use? Addiction 104: 138-149, 2009.

60) Sandseter EBH, and Kennair LEO. Children's risky play from an evolutionary perspective: The antiphobic effects of thrilling experiences. Evol Psychol 9: 257-284, 2011.

61) Sandseter EBH. Categorising risky play-how can we identify risk-taking in children's play? Eur Early Child Educ Res J 15: 237-252, 2007.

62) Sandseter EBH. Characteristics of risky play. J Adventure Educ Outdoor Learn 9: 3-21, 2009.

63) Brussoni M, Gibbons R, Gray C, Ishikawa T, Sandseter EB, Bienenstock A, Chabot G, Fuselli P, Herrington S, Janssen I, Pickett W, Power M, Stanger N, Sampson M, Tremblay MS. What is the relationship between risky outdoor play and health in children? a systematic review. Int $J$ Environ Res Public Health 12: 6423-6454, 2015.

64) Prezza M, Pilloni S, Morabito C, Sersante C, Alparone FR, Giuliani MV. The influence of psychosocial and environmental factors on children's independent mobility and relationship to peer frequentation. J Community Appl Soc Psychol 11: 435-450, 2001.

65) Pellegrini A. Elementary-school children's roughand-tumble play and social competence. Dev Psychol 24: 802-806, 1988.

66) Pellegrini AD. Elementary school children's roughand-tumble play. Early Child Res Q 4: 245-260, 1989.

67) DeWolf D. Preschool children's negotiation of intersubjectivity during rough and tumble play, Louisiana State University: Baton Rouge, LA, USA, 1999.

68) Colwell MJ, Lindsey EW. Preschool children's pretend and physical play and sex of play partner: connec- tions to peer competence. Sex Roles 52: 497-509, 2005.

69) Pellegrini AD. A Longitudinal study of boys' roughand-tumble play and dominance during early adolescence. J Appl Dev Psychol 16: 77-93, 1995.

70) Hayward DG, Rothenberg M, Beasley RR. Children's play and urban playground environments: a comparison of traditional, contemporary, and adventure playground types. Environ Behav 6: 131-168, 1974.

71) Bundy AC, Luckett T, Tranter PJ, Naughton GA, Wyver SR, Ragen J, Spies G. The risk is that there is "no risk": a simple, innovative intervention to increase children's activity levels. Int J Early Years Educ 17: 33-45, 2009.

72) Tremblay MS, Gray C, Babcock S, Barnes J, Bradstreet CC, Carr D, Chabot G, Choquette L, Chorney D, Collyer C, Herrington S, Janson K, Janssen I, Larouche R, Pickett W, Power M, Sandseter EB, Simon B, Brussoni M. Position statement on active outdoor play. Int J Environ Res Public Health 12: 6475-6505, 2015.

73) Hüttenmoser M. Children and their living surroundings: empirical investigation into the significance of living surroundings for the everyday life and development of children. Child Environ 12: 403-413, 1995.

74) Dowdell K, Gray T, Malone K. Nature and its influence on children's outdoor play. Aust J Outdoor Ed 12: 24-35, 2011.

75) Korpela K, Kytta M, Hartig T. Restorative experience, self-regulation, and children's special place preferences. J Environ Psychol 22: 387-398, 2002.

76) Becker DR, McClelland MM, Loprinzi P, Trost SG. Physical activity, self-regulation, and early academic achievement in preschool children. Early Educ Dev 25: 56-70, 2014.

77) Lavrysen A, Bertrands E, Leyssen L, Smets L, Vanderspikken A, De Graef P. Risky-play at school. facilitating risk perception and competence in young children. Eur Early Child Educ 25: 89-105, 2015.

78) Veitch J, Bagley S, Ball K, Salmon J. Where do children usually play? a qualitative study of parents' perceptions of influences on children's active free-play. Health Place 12: 383-393, 2006.

79) McArdle K, Harrison T, Harrison D. Does a nurturing approach that uses an outdoor play environment build resilience in children from a challenging background? J Adventure Ed Outdoor Learn 13: 238-254, 2013.

80) Kochanowski L, Carr V. Nature playscapes as contexts for fostering self-determination. Child. Youth Environ 24: 146-167, 2014.

81) Canning N. "Where's the bear? Over there!"-creative thinking and imagination in den making. Early Child Dev Care 183: 1042-1053, 2013.

82) Gray P. The decline of play and the rise of psychopathology in children and adolescents. Amer J Play 3: 443-463, 2011.

83) Maas JM, Verheij RA, Vries SD, Spreeuwenberg P, Schellevis FG, Groenewegen PP. Morbidity is related 
to a green living environment. J Epidemiol Community Health 63: 967-973, 2009.

84) McCurdy LE, Winterbottom KE, Mehta SS, Roberts JR. Using nature and outdoor activity to improve children's health. Curr Probl Pediatr Adolesc Health Care 40: 102-117, 2010.

85) Wells NM. At home with nature: effects of "greenness" on children's cognitive functioning. Environ Behav 32: 775-795, 2003.

86) Glosser G and Goodglass H. Disorders in executive control functions among aphasic and other brain damaged patients. J Clin Exp Neuropsychol 12: 485-501, 1990.

87) Mole M, Marshall L, Pietrowsky R, Lutzenberger W. Dimensional complexity of the EEG indicates a right frontocortical locus of attentional control. Psychophysiology 9: 45-55, 1995.

88) Coull JT, Frackowiak RSJ, Frith CD. Monitoring for target objects: activation of right frontal and parietal cortices with increasing time on task. Neuropsychologia 36: 1325-1334, 1998.

89) Wells NM, Evans GW. Nearby nature: a buffer of life stress among rural children. Environ Behav 35: 311330, 2003.

90) Taylor AF, Kuo FE, Sullivan WC. Coping with ADD: The surprising connection to green play settings. Environ Behav 33: 54-77, 2001.

91) Kuo FE, Taylor AF. A potential natural treatment for attention-deficit/hyperactivity disorder: evidence from a national study. Am J Public Health 94: 15801586, 2004.

92) Taylor AF, Kuo FE. Children with attention deficits concentrate better after walk in the park. $J$ Atten Disord 12: 402-409, 2009.

93) Mainella FP, Agate JR, Clark BS. Outdoor-based play and reconnection to nature: a neglected pathway to positive youth development. New Dir Youth Dev 2011: 89-104, 2011.

94) Janssen I. Estimating Whether Replacing Time in Active Outdoor Play and Sedentary Video Games With Active Video Games Influences Youth's Mental Health. J Adolesc Health 59: 517-522, 2016.

95) Telama R. Tracking of physical activity from childhood to adulthood: a review. Obes Facts 2: 187-195, 2009 .

96) Tammelin T, Näyhä S, Hills AP, Järvelin MR. Adolescent participation in sports and adult physical activity. Am J Prev Med 24: 22-28, 2003.

97）内閣府経済社会総合研究所. 平成 26 年度県民経済計算 について, http://www.esri.cao.go.jp/jp/sna/data/data_ list/kenmin/files/contents/pdf/gaiyou.pdf\#search (平成 29 年 10 月 25 日現在)

98) 文部科学省. 体育・スポーツ施設現況調査結果の概要, http://www.mext.go.jp/b_menu/toukei/chousa04/shisetsu/kekka/1261398.htm（平成29年10月25日現在）

99）平塚寛之, 引原有輝 : 街区公園の現状分析ならびに子 どもの利用状況と興味関心, 発育発達研究, 67: 1-15, 2015.

100) Bohn-Goldbaum EE, Phongsavan P, Merom D, Rogers K, Kamalesh V, Bauman AE. Does playground improvement increase physical activity among children? A quasi-experimental study of a natural experiment. J Environ Public Health 2013: 109841, 2013. 